\section{AGRIEKONOMIKA}

http://journal.trunojoyo.ac.id/agriekonomika

Volume 9, Nomor 1, 2020

https://doi.org/10.21107/agriekonomika.v9i1.6216
Agriekonomika has been accredited as a scientific journal by the Ministry of

Research-Technology and Higher Education Republic of Indonesia: No.

23/E/KPT/2019

\title{
Pengaruh Keputusan Petani Kopi Rakyat dalam Pemilihan Sistem Kopi Organik dan Non Organik di Jawa Timur
}

\author{
${ }^{\otimes}$ S Sudarko, ${ }^{2}$ Sumardjo, ${ }^{2}$ Anna Fatchiya, ${ }^{2}$ Prabowo Tjitropranoto \\ ${ }^{1}$ Program Studi Penyuluhan Pertanian Universitas Jember, Indonesia \\ ${ }^{2}$ Fakultas Ekologi Manusia Institut Pertanian Bogor, Indonesia \\ Received: December 2019; Accepted: April 2020; Published: April 2020
}

\begin{abstract}
ABSTRAK
Petani kopi rakyat organik mulai berkembang di Jawa Timur. Tujuan penelitian ini yaitu: mengetahui tingkat dan perbedaan karakteritik petani kopi organik dan non organik dan dukungan penyuluhan, menganalisis faktor-faktor pengaruh keputusan petani kopi dalam menerapkan sistem organik dan non organik. Penelitian dilaksanakan di di Kabupaten Bondowoso dan Malang, Jawa Timur. Sampel penelitian berjumlah 376 petani kopi (120 organik dan 256 non organik). Penelitian menggunakan metode survai. Data dianalisis dengan metode deskriptif, Uji-t dan Regresi Binary Logistic. Hasil penelitian menunjukkan bahwa pendidikan non formal, skala usaha, penguasaan lahan, kekosmopolitan, dukungan penyuluhan pemerintah dan swasta kategori rendah, sedangkan umur petani, pendidikan formal, motivasi, pengalaman, dukungan penyuluh swadaya pada kategori sedang. Terdapat perbedaan signifikan pada peran penyuluhan sebagai fasilitator, motivator dan mediator, pemanfaatan teknologi informasi, umur, pengalaman, motivasi dan kekosmopolitan. Faktor yang berpengaruh signifikan terhadap keputusan petani menerapkan sistem kopi organik yaitu: pendidikan formal dan non formal, motivasi, kekosmopolitan, penyuluh swadaya dan swasta.
\end{abstract}

Kata Kunci: Keputusan Petani Kopi Rakyat, Sistem Kopi Organik, Sistem Kopi Non Organik

Influence Coffee Smallholder Farmer' Decisions in the Selection of Organic and NonOrganic in East Java Province

\begin{abstract}
Organic coffee smallholders grow in East Java. The purpose of this research is to determine the level and differences in characteristics of coffee farmers and support of extension to farmers, and analyze the factors that influence farmers' decision making in implementing organic and non-organic systems. The research was conducted in Bondowoso Regency and Malang, East Java. The research sample consisted of 376 coffee farmers. Data were analyzed using descriptive methods, $t$-test and binary logistic regression. The results showed that non-formal education, business scale, land tenure, cosmopolitan, government and private extension support in the low category, while the age of farmers, formal education, motivation, experience, farmers to farmers extension support in the medium category. There are significant differences in the role of extension as facilitators, motivators and mediators, the use of information technology, age, experience, motivation and cosmopolitan. Factors that have a significant influence on farmers' decisions to implement organic farming systems are: formal and non-formal education, motivation, cosmopolitan, farmer to farmer extension and private extension.
\end{abstract}

Keywords: Coffee Farmer' Decisions, Organic Coffee Farming, Non Organic Coffee Farming 


\section{PENDAHULUAN}

Perkebunan kopi merupakan sektor yang penting bagi perekonomian Indonesia dan juga menjadi komoditas unggulan di wilayah Jawa Timur. Komoditas kopi menjadi produk unggulan Indonesia dalam perdagangan internasional. Pembangunan perkebunan kopi terus diarahkan pada pengembangan kopi organik. Peluang dan tren kopi organik di pasar global cenderung meningkat, hingga pada tahun 2020 permintaan kopi dunia terus meningkat sebesar 2,5 persen pertahunnya (Direktur Jenderal Perkebunan, 2017). Indonesia sebagai produsen kopi terbesar ke 4 berusaha merespon peluang pasar tersebut dengan pengembangan pertanian kopi rakyat organik. Hal ini untuk menghadapi perubahan perilaku konsumen kopi yang mengarah pada produk kopi yang khusus atau spesialty coffee serta memperhatikan aspek keberlanjutan lingkungan. Namun, sampai saat ini dalam pengembangan kopi secara non organik saja petani kopi rakyat masih banyak menghadapi permasalahan seperti pengolahan masih tradisional, skala usaha masih kecil dan pendapatan masih rendah karena kualitas dan produktivitas juga masih rendah (Aklimawati dkk., 2015; Hafif dkk., 2014). Maka dari itu sistem pertanian kopi organik sebagai inovasi baru bagi petani masih menghadapi banyak tantangan dan juga berbagai permasalahan seperti dalam proses adopsi, rendahnya produktivitas dan permasalahan koordinasi struktural dengan pihak-pihak kelembagaan terkait serta sulitnya petani kopi rakyat dalam menembus pasar potensial. Petani kopi rakyat sebagai individu menurut Hawkins \& van den Ban (1999), sebaiknya diarahkan secara partisipatif dalam memutuskan penerapan suatu inovasi dan teknologi baru seperti pertanian organik. Oleh sebab itu penguatan karakteristik individu adopter melalui program penyuluhan sangat penting dalam upaya meningkatkan daya saing dan kapasitas untuk keberhasilan pengembangan pertanian kopi organik. Petani kopi rakyat di wilayah Jawa Timur oleh pihak pemerintah mulai dikembangkan sistem pertanian organik dengan program percontohan beberapan kelompok tani kopi rakyat sebagai pilot project go organic. Sebagai inovasi baru, keberhasillan pengembangan kopi organik sangat ditetukan pada proses pengambilan keputusan oleh tingkat individu petani kopi rakyat. Mengetahui faktor internal dan eksternal yang berpengaruh kuat dari lingkungan petani kopi penting dan bernilai strategis untuk bekal kebijakan pengembangan program kopi rakyat organik. Hal ini didukung oleh hasil penelitian sebelumnya bahwa keberhasilan suatu inovasi dan teknologi sangat ditentukan karakter individualitas yang baik dari setiap calon adopternya. Petani kopi akan mudah mencapai tujuannya jika mampu berkelompok dan setiap individu memiliki modal sosial yang tinggi (Sumarti dkk., 2017).

Beberapa penelitian yang terkait dengan pertanian kopi organik telah menemukan bahwa sistem pertanian kopi organik masih tradisional, peralatan yang masih sederhana namun sudah dapat keuntungan sebesar $200 \%$ dibandingkan cara konvesional/non organik (Rubiyo dkk., 2003). Menurut Rizki dkk. (2017), bahwa petani kopi organik memiliki persepsi baik terhadap program sertifikasi organik, faktor karakteristik yang memiliki korelasi kuat dengan persepsi petani adalah pengalaman, pendidikan, dan motivasi. Untuk karakteristik petani umur dan pendapatan memiliki korelasi yang rendah. Hasil kajian Rubiyo dkk. (2003), menunjukkan jumlah produksi kopi yang diberi pupuk organik tertinggi dengan rata-rata 948,80 kg kopi beras/ha dengan keuntungan $\mathrm{Rp}$ 863.800/tahun dengan tingkat R/C 1,35. Gani (2008), melaporkan bahwa peningkatan pendapatan petani kopi organik belum mampu meningkatkan kesejahteraan. Petani kopi organik hanya sekedar menjual produksinya ke para distributor atau pedagang lokal.

Diperlukan upaya strategis dari seluruh pemangku kepentingan untuk meningkatkan pendapatan petani kopi. Fatmalasari dkk. (2016), menyatakan 
sertifikasi kopi organik dapat memberikan manfaat bagi petani praktik budidaya kopi yang berkelanjutan secara ekonomi, lingkungan dan sosial. Manfaat sertifikat organik tersebut berupa peningkatan efisiensi biaya kopi, namun belum memberikan manfaat dalam peningkatan produktivitas, harga kopi dan pendapatan usahatani kopi. Gani (2008), juga menyatakan bahwa pendapatan petani kopi organik lebih besar dibandingkan pendapatan petani kopi non organik. Harga jual produk kopi organik lebih tinggi dibandingkan harga kopi non organik. Rendahnya pendapatan petani kopi disebabkan oleh dua faktor utama yaitu rendahnya produktivitas dan rendahnya harga. Petani kopi belum menerapkan Good Agriculture Practice (GAP) secara menyeluruh dan terdapat hama dan penyakit yang tinggi. Petani kopi memiliki pengetahuan yang terbatas tentang GAP. Perbaikan harga petani dapat ditempuh dengan meningkatkan mutu produksi dan perbaikan jalur distribusi penjualan dapat digunakan sebagai strategi peningkatan pendapatan petani kopi. Lebih lanjut Rubiyo dkk. (2003), menjelaskan bahwa karakter dan teknik usahatani berpengaruh terhadap kapasitas petani dalam mengadopsi suatu lingkungan baru. Mengingat dukungan penyuluhan kepada petani organik masih rendah. (Sumarti dkk., 2017) berpendapat untuk pemberdayan petani kopi perlu dukungan penyuluhan dan pendampingan usaha kopi berbasis informasi dan teknologi. Namun menurut Ruhimat (2015) dan Managanta dkk. (2019), motivasi petani dalam berusahatani masih rendah. Mayrowani (2013), juga menemukan bahwa petani kopi masih rendah dalam pengolahan atau pascapanen sehingga belum dapat insentif harga yang memadai sehingga masih butuh dukungan kelembagaan dan kemitraan. Walaupun demikian, masih jarang terungkap yang mengkaji tentang perbedaan dukungan penyuluhan dan karakteristik petani kopi baik jenis Arabika dan Robusta yang menerapkan sistem pertanian organik bersertifikat dan petani kopi yang belum menerapkan pertanian organik. Selain itu, belum banyak informasi tentang faktor-faktor apa yang berpengaruh dalam menentukan keputusan petani kopi rakyat untuk memilih menerapkan sistem pertanian kopi organik dan atau tetap memilih mempertahankan sistem pertanian konvensional non organik.

Berdasarkan latar belakang tersebut penelitian ini akan membandingkan perbedaan dan persamaan dari aspek karakteristik dan dukungan penyuluhan pemerintah, swadaya, swasta pada sentra petani kopi yang sudah menerapkan sistem pertanian organik bersertifikat nasional dan internasional dengan petani kopi yang belum menerapkan sistem pertani organik secara menyeluruh serta belum mendapatkan sertifikat organik. Maka dari itu tujuan penelitian ini yaitu: (1) mengetahui tingkat dan perbedaan karakteristik petani kopi organik dan non organik dan dukungan penyuluhan pemerintah, swadaya dan swasta dalam pengembangan pertanian organik dan non organik dan (2) menganalisis faktor-faktor yang berpengaruh terhadap pengambilan keputusan petani kopi rakyat dalam sistem pertanian organik dan non organik di wilayah sentra kopi rakyat di Jawa Timur.

\section{METODE PENELITIAN}

Penelitian ini menggunakan metode survei. Waktu pelaksanan penelitian pada rentang bulan Agustus-Oktober 2019. Lokasi penelitian dipilih secara purposive, yaitu di Kabupaten Malang dan Kabupaten Bondowoso Provinsi Jawa Timur dengan pertimbangan merupakan sentra utama pengembangan komoditas kopi rakyat sesuai dengan keputusan Menteri Pertanian Nomor 830 Tahun 2016 tentang penetapan kawasan pertanian nasional (Direktur Jenderal Perkebunan, 2017). Kabupaten Bondowoso representatif dari jenis kopi Arabika dengan topografi yang tinggi, sedangkan untuk Kabupaten Malang representatif kopi jenis Robusta dengan topografi sedang. Selain itu kedua lokasi tersebut sama-sama memiliki pilot project kopi organik. 
Populasi penelitian ini adalah semua petani kopi yang bergabung dalam kelompok tani di wilayah sentra produksi kopi di Kabupaten Malang dan Bondowoso. Jumlah populasi 6.470 orang terdiri dari 917 orang dari Kabupaten Bondowoso dan sebesar 5.553 orang dari Kabupaten Malang (Direktur Jenderal Perkebunan, 2017). Penentuan jumlah sampel dengan menggunakan rumus Slovin dengan margin of error lima persen diperoleh 376 responden. Responden tersebut terdiri dari 120 petani kopi organik dan 256 petani kopi non organik. Responden petani organik bersertifikat diambil dengan metode quota sampling sedangkan untuk responden petani kopi non organik diambil dengan proporsional cluster random sampling dari seluruh wilayah sentra kopi rakyat (Arikunto, 2010; Saragih, 2018). Wilayah Kabupaten Bondowoso meliputi Kecamatan Sumberwringin, Sempol, Sukosari, Maesan dan Pakem, sedangkan Kabupaten Malang meliputi Kecamatan Dampit, Tirtoyudo, Sumbermanjing, Ampelgading, Wonosari dan Poncokusuma. Data kualitatif dikumpulkan dengan melakukan observasi, wawancara mendalam dan diskusi kelompok dengan pihak-pihak terkait seperti Kepala Dinas Pertanian, penyuluh pertanian, ketua kelompok tani, pedagang kopi, petani maju, Badan Pembanguna Daerah dan stakeholders kopi lainnya.

Definisi operasional yang digunakan untuk petani kopi organik adalah petani kopi yang sudah menerapkan menyeluruh sistem pertanian bebas bahan kimiawi dan mendapatkan sertifikasi organik dari Lembaga Sertifikasi Organik (LSO) baik dari nasional dan internasional. Untuk petani organik jenis Arabika wilayah Kabupaten Bondowoso sudah mendapat sertifikat nasional SNI organik dan sertifikat internasional ACT organic dan Rainforest Alliance. Sedangkan untuk wilayah Kab. Malang jenis kopi Robusta sudah mendapat sertifikat nasional organik dari LeSOS dan sertifikat internasional UTZ dan $4 C$ certified. Sedangkan petani non organik adalah petani kopi yang belum menerapkan sistem perkebunan organik dan belum memiliki sertifikat organik.

Variabel karakteristik petani dukungan penyuluhan pemerintah, penyuluh swadaya dan swasta, diukur dengan skor pendekatan skala likert (1-4) data total skor kemudian ditranformasikan dengan nilai rentang (0-100). Penelitian ini menggunakan validitas konstruktif dan isi dengan analisis korelasi product moment dari Karl Pearson (Arikunto S., 2010). Nilai koefisien korelasi $\geq 0,3$ maka butirbutir instrumen sudah valid, sedangkan pengujian reliabilitas Cronbach alpha dengan menguji coba instrumen kepada petani kopi kopi di 30 anggota kelompok tani kopi Sidomulyo 1 di Desa Sidomulyo Kecamatan Silo Kabupaten Jember Jawa Timur pada bulan Juli 2019. Pada variabel karakteristik koefisien korelasi 0,6010,855 dan dukungan penyuluhan antara 0,396-0,872 yang artinya instrumen sudah valid. Hasil uji reliabilitas dengan Cronbach alpha mendapatkan nilai sebesar 0,840 dan 0,683 yang berarti instrument penelitian untuk karakteristik dan dukungan penyuluhan reliabel atau layak untuk pengambilan data penelitian.

Analisis data pada tujuan pertama, untuk mengetahui tingkat dan perbedaan karakteristik petani kopi organik dan non organik dan dukungan penyuluhan pemerintah, swadaya dan swasta dalam pengembangan pertanian organik dan non organik dilakukan dengan analisis deskriptif (program Excel dan SPSS PASW) dan uji beda ( $u j i$ t independent test). Penyajian rumus dan keterangan dari rumus dapat dilihat di bawah:

$$
t=\frac{\bar{x}_{a}-\bar{x}_{b}}{\sqrt{\left(\frac{S_{a}^{2}}{n_{a}}\right)+\left(\frac{S_{b}^{2}}{n_{b}}\right)}}
$$

Di mana Xa merupakan rata-rata sumbangan nilai karakteristik usahatani kopi organik bersertifikat, $\mathbf{X b}$ adalah rata-rata sumbangan nilai karakteristik usahatani kopi non organik. Sa adalah standar deviasi sumbangan nilai karakteristik usahatani kopi organik bersertifikat. Sb adalah standar deviasi 
sumbangan sumbangan nilai karakteristik usahatani kopi non organik. na adalah jumlah sampel petani kopi organik bersertifikat. nb adalah jumlah sampel petani kopi non organik bersertifikat. Kriteria Pengambilan keputusan: (a) Jika $t_{\text {hitung }}>t_{\text {tabel }}$ atau signifikansi $\left(P_{\text {value }}\right) \leq$ 0,05 maka $\mathrm{HO}$ ditolak berarti terdapat perbedaan karakteristik antara kopi organik bersertifikat dengan kopi nonorganik. b. Jika $t_{\text {hitung }}<t_{\text {tabel }}$ atau signifikansi ( $P$ value) $>0,05$ maka $\mathrm{HO}$ diterima berarti tidak terdapat perbedaan karakteristik antara kopi organik bersertifikat dengan kopi non organik.

Tujuan kedua, untuk menganalisis faktor-faktor yang berpengaruh terhadap pengambilan keputusan petani kopi rakyat dalam sistem pertanian organik dan non organik dilakukan dengan menggunakan analisis regresi logistik binary. Penyajian rumus dan keterangan dari rumus dapat dilihat di bawah:

$$
\begin{aligned}
Y= & \beta 0+\beta 1 \times 1.1+\beta 2 \times 1.2+\beta 3 \times 1.3+\beta 4 \\
& X 1.4+\beta 5 \times 1.5+\beta 6 \times 1.6+\beta 7 \times 1.7+ \\
& \beta 8 \times 1.8+\mu i
\end{aligned}
$$

Di mana $\mathbf{Y}$ adalah faktor dependent (sistem usahatani kopi rakyat, 0 adalah memilih non organik, 1 adalah memilih organik. Selanjutnya, $\mathbf{X}$ adalah faktorfaktor independent: $\mathbf{X} 1$ adalah karakteristik petani kopi, (X1.1 adalah umur petani (tahun), X1.2 adalah pendidikan formal (tahun), X1.3 adalah pendidikan nonformal (frekuensi/tahun), X1.4 adalah pengalaman berusahatani kopi (tahun), X1.5 adalah motivasi pengembangan usaha (skor). X1.6 adalah penguasaan lahan (ha), X1.7 adalah kekosmopolitan (Frekuensi/ semester), X1.8 adalah skala usaha (skor), X2 adalah dukungan penyuluhan pemerintah (skor), $\mathbf{X} 3$ adalah penyuluh swadaya (skor) dan X4 adalah penyuluh swasta (skor).

\section{HASIL DAN PEMBAHASAN}

Tingkat dan Perbedaan Karakteristik petani kopi organik dan non organik

Karakteristik petani kopi dalam penelitian ini yaitu: umur, pendidikan formal, pendidikan non formal, pengalaman berusahatani, motivasi pengembangan usaha, pe- nguasaan lahan, kekosmopolitan, dan skala usaha tani. Secara rinci perbedaan karakteristik petani kopi dapat dilihat pada Tabel 1.

Tabel 1, menunjukkan bahwa ratarata umur secara keseluruhan adalah 50,6 tahun yang masuk pada kategori madya atau usia produktif. Untuk petani kopi organik rata-rata umur petaninya lebih tua sedikit dari pada umur petani kopi non organik. Hal ini mengindikasikan bahwa petani yang berani mengambil risiko terhadap inovasi baru adalah petani yang memiliki pengalaman lebih lama dalam berusahatani kopi atau petani yang memiliki umur lebih lanjut. Kondisi ini terjadi juga karena program pertanian organik merupakan program yang sifatnya top down sehingga penginisiasi dan pembina program menunjuk kelompok tani kopi yang sudah berpengalaman dan sudah terbukti aktif dalam kurun waktu yang lama sehingga peluang berhasilnya program sekalian untuk program percontohan bagi petani kopi lainnya. Tabel 2 menunjukkan bahwa antara umur petani kopi organik dan non organik terdapat perbedaan yang signifikan. Kondisi ini berbeda dengan hasil penelitian Pratama \& Setiawan (2018), bahwa petani organik dan non organik tidak ada perbedaan semua dalam kategori usia lanjut atau tidak produktif.

Berdasarkan Tabel 1, dapat dilihat bahwa rata-rata pendidikan formal petani kopi rakyat yaitu lulus Sekolah SD atau Sekolah SMP yang masuk kategori rendah dan sedang. Selain itu petani organik memiliki rata-rata pendidikan formal yang lebih rendah dibandingkan dengan petani kopi non organik. Tidak ada perbedaan yang signifikan antara pendidikan formal petani kopi organik dan non organik. Pendidikan formal petani kopi yang cenderung sedang untuk meningkatkan kemampuannya membutuhkan pendekatan komunikasi yang mudah dipahami dengan metode partisipatif dan dialogis. Hal ini berbeda dengan hasil penelitian sebelumnya bahwa pendidikan petani perkebunan rakyat masuk kategori rendah. (Managanta dkk., 2019). 
Frekuensi petani kopi dalam mengikuti nonorganik, namun tidak ada perbedaan pendidikan non formal seperti pelatihan, yang signifikan antara pendidikan non sekolah lapang, seminar, workshop dan formal petani kopi organik dan non studi banding terkait usaha tani kopi. Tabel organik. Implikasinya supaya program 1, menunjukkan bahwa rata-rata total pertanian kopi organik dapat lebih berhasil frekuensi petani kopi mengikuti pendidikan maka pihak-pihak terkait sebaiknya menon formal pada kategori rendah ( $>3 \mathrm{kali} /$ ningkatkan program pelatihan, sekolah tahun). Rata-rata pendidikan non formal lapang dan meningkatkan ketrampilan petani organik lebih besar dari pada rata- usahatani kopi lainnya. Hal ini sesuai rata pendidikan non formal petani kopi dengan pendapat Managanta dkk.

Tabel 1

Sebaran, Rataan dan Perbedaan Karakteristik Petani Kopi Organik dan Non Organik di Kabupaten Bondowoso dan Malang Jawa Timur

\begin{tabular}{|c|c|c|c|c|c|}
\hline \multirow{2}{*}{ Karakteristik } & \multirow{2}{*}{ Kategori } & \multicolumn{2}{|c|}{$\begin{array}{l}\text { Petani Kopi Kabupaten } \\
\text { Bondowoso dan Malang }\end{array}$} & \multirow{2}{*}{$\begin{array}{c}\text { Total } \\
(n=376)\end{array}$} & \multirow{2}{*}{$\begin{array}{l}\text { Uji Beda } \\
\text { (T-test) }\end{array}$} \\
\hline & & $\begin{array}{c}\text { Organik } \\
(n=120)(\%)\end{array}$ & $\begin{array}{l}\text { Non organik } \\
(n=256)(\%)\end{array}$ & & \\
\hline \multirow{4}{*}{$\begin{array}{l}\text { Umur Petani } \\
(X 1.1)\end{array}$} & Muda $(<=34$ tahun) & 12,5 & 6,8 & 8,5 & \multirow[t]{4}{*}{$0,02^{*}$} \\
\hline & Madya (35-54 tahun) & 46,7 & 54,8 & 52,1 & \\
\hline & Lanjut (>= 55tahun) & 40,8 & 38,4 & 39,4 & \\
\hline & Rataan (Tahun) & 51,7 & 50,2 & 50,6 & \\
\hline \multirow{4}{*}{$\begin{array}{l}\text { Pendidikan Formal } \\
\text { (X1.2) }\end{array}$} & Rendah (0-6 tahun/Lulus SD) & 59,2 & 46,1 & 50,3 & \multirow[t]{4}{*}{0,13} \\
\hline & Sedang (7-12 tahun/Lulus SMP) & 37,5 & 50,8 & 46,5 & \\
\hline & $\begin{array}{l}\text { Tinggi (>= } 13 \text { tahun/Lulus } \\
\text { SMU) }\end{array}$ & 3,3 & 3,1 & 3,2 & \\
\hline & Rataan (Tahun) & 7,8 & 8,2 & 8,1 & \\
\hline \multirow{4}{*}{$\begin{array}{l}\text { Pendidikan non } \\
\text { formal (X1.3) }\end{array}$} & Rendah ( $<=3$ kali) & 65,8 & 72,2 & 70,2 & \multirow[t]{4}{*}{0,43} \\
\hline & Sedang (4-5 kali) & 30,0 & 18,4 & 22,1 & \\
\hline & Tinggi (>= 6 kali ) & 4,2 & 9,4 & 7,7 & \\
\hline & Rataan (Kali) & 2,8 & 2,7 & 2,8 & \\
\hline \multirow{4}{*}{$\begin{array}{l}\text { Pengalaman beru- } \\
\text { sahatani }(X 1.4)\end{array}$} & Rendah (<=15 Tahun) & 54,2 & 53,9 & 54,0 & \multirow[t]{4}{*}{$0,00^{* *}$} \\
\hline & Sedang (16-33 Tahun) & 31,7 & 36,3 & 34,8 & \\
\hline & Tinggi (>= 34 Tahun) & 14,2 & 9,8 & 11,2 & \\
\hline & Rataan (Tahun) & 16,5 & 16,0 & 16,2 & \\
\hline \multirow{4}{*}{$\begin{array}{l}\text { Motivasi Pengem- } \\
\text { bangan usaha } \\
(\mathrm{X} 1.5)\end{array}$} & Rendah (<=31) & 14,2 & 3,9 & 7,2 & \multirow[t]{4}{*}{$0,01^{*}$} \\
\hline & Sedang (32-65) & 55,0 & 45,7 & 48,7 & \\
\hline & Tinggi $(>=66)$ & 30,8 & 50,4 & 44,1 & \\
\hline & Skor Rataan & 51,9 & 64,5 & 60,5 & \\
\hline \multirow{4}{*}{$\begin{array}{l}\text { Penguasaan } \\
\text { lahan (X1.6) }\end{array}$} & Sempit $(<0,5 \mathrm{Ha})$ & 14,2 & 3,9 & 7,2 & \multirow[t]{4}{*}{0,06} \\
\hline & Sedang $(0,5-9,0 \mathrm{Ha})$ & 55,0 & 45,7 & 48,7 & \\
\hline & Luas $(>=10 \mathrm{Ha})$ & 30,8 & 50,4 & 44,1 & \\
\hline & Rataan (Ha) & 0,8 & 1,1 & 1,0 & \\
\hline \multirow{4}{*}{$\begin{array}{l}\text { Kekosmopolitan } \\
\text { (X1.7) }\end{array}$} & Lokalit $(<=18)$ & 91,7 & 98,8 & 96,5 & \multirow[t]{4}{*}{$0,00^{\star *}$} \\
\hline & Cukup (19-34) & 5,0 & 0,8 & 2,1 & \\
\hline & Kosmopolit (>= 35) & 3,3 & 0,4 & 1,3 & \\
\hline & Rataaan (Kali) & 7,0 & 4,5 & 5,3 & \\
\hline \multirow{4}{*}{$\begin{array}{l}\text { Skala usaha } \\
\text { (X1.8) }\end{array}$} & Kecil $(<34)$ & 96,7 & 89,8 & 92,0 & \multirow[t]{4}{*}{0,08} \\
\hline & Menengah (35-69) & 2,5 & 8,6 & 6,6 & \\
\hline & Besar $(>=70)$ & 0,8 & 1,6 & 1,3 & \\
\hline & Skor Rataan & 32,8 & 34,0 & 33,6 & \\
\hline
\end{tabular}

Keterangan :**Berbeda sangat signifikan pada taraf $(0,01),{ }^{*}$ berbeda signifikan pada taraf $(0,05)$ Sumber: Pengolahan Data Primer, 2019 
(2019), bahwa pendidikan non formal petani perkebunan masih kategori rendah sehingga butuh ditingkatkan.

Pengalaman berusahatani petani kopi rata-rata masuk kategori sedang yaitu 16,2 tahun. Sesuai dengan hasil wawancara dengan petani kopi bahwa sebagian besar budidaya kopi rakyat merupakan warisan usaha dari orang tua atau nenek moyangnya jadi bersifat turun temurun. Ada perbedaan yang sangat signifikan antara pengalaman petani kopi organik dan non organik. Selaras dengan temuan Managanta dkk. (2019), bahwa pengalaman petani perkebunan masuk dalam kategori sedang.

Motivasi petani kopi yang dimaksud dalam penelitian ini adalah besarnya kemauan petani untuk merencanakan pengembangan kopi yang lebih maju. Berdasarkan Tabel 1, dapat dilihat bahwa rata-rata skor total motivasi petani kopi dalam kategori sedang. Motivasi petani non organik secara rata-rata lebih besar dari pada petani kopi organik dan ada perbedaan yang signifikan antara motivasi petani kopi organik dan non organik. Hal ini terjadi karena banyak petani yang masih merasa bimbang atau ragu walaupun sudah menerapkan sistem organik secara menyeluruh karena belum sepenuhnya ada bukti nyata bagi petani kopi yang beralih pada sistem perkebunan kopi organik mendapatkan tingkat kesejahteraan yang signifikan, mengingat program perkebunan kopi organik masih berjalan 2-4 tahun setelah masa konversi sehingga banyak petani kopi yang pada tahap konfirmasi untuk mengadopsi sistem pertanian organik. Hal ini berbeda dengan hasil penelitian Rizki dkk. (2017), bahwa persepsi petani kopi terhadap pertanian organik sudah baik. Namun, sesuai dengan pendapat Managanta dkk. (2019), motivasi petani perkebunan dalam memenuhi kebutuhannya pada kategori sedang.

Petani kopi rakyat di Kabupaten Malang sebagian besar lahan kebun kopinya milik sendiri dan sisanya sewa, sedangkan untuk wilayah di Kabupaten
Bondowoso sebagian besar lahan kebun kopi ada di dalam hutan milik pemerintah (hutan lindung atau hutan produksi Perhutani). Berdasarkan Tabel 1 dapat dilihat bahwa rata-rata penguasaan lahan petani kopi rakyat dengan luasan 1 ha dan tidak ada perbedaan yang signifikan antara penguasaan lahan petani kopi organik dan non organik. Hampir sama dengan temuan penelitian sebelumnya bahwa rata-rata luas kopi organik di Aceh yaitu 1,26 ha. Hal ini sesuai dengan hasil penelitian (Pratama dan Setiawan, 2018) bahwa luas lahan petani organik dan non organik di Kabupaten Kudus tidak ada perbedaan yang signifikan. Kekosmopolitan dalam penelitian ini merupakan frekuensi petani dalam menjalin komunikasi, konsultasi dan hubungan dengan pihak luar wilayah desa untuk pengembangan usaha tani kopinya. Berdasarkan data lapang, bahwa petani kopi keluar wilayah desanya untuk menemui atau konsultasi dengan penyuluh, pedagang, petani maju dan peneliti kopi. Berdasarkan Tabel 1 dapat dilihat bahwa rata-rata frekuensi petani keluar desa dalam kategori lokalit atau rendah dan tidak ada perbedaan yang signifikan antara pendidikan formal petani kopi organik dan non organik. Hal ini terjadi mengingat memang sebagian besar lokasi tempat tinggal kebun kopi berada pada wilayah perbukitan dan pegunungan yang masih terpencil dan akses jalan yang cukup sulit, sehingga membuat petani kopi enggan atau jarang bepergian untuk mencari informasi usahatani kopi. Petani kopi organik secara rata-rata lebih kosmopolit dibandingkan dengan petani non organik.

Skala usahatani kopi merupakan tingkatan besar pengelolaan kopi oleh petani yang dicerminkan dengan jumlah aset keberadaan peralatan, perlengkapan sarana produksi usaha tani kopi (mencerminkan tingkat pengolahan primer, sekunder dan tersier). Skala usahatani tidak memakai ukuran luas ahan dan jumlah pohon kopi dengan pertimbangan luas lahan sudah masuk variabel tersendiri variabel penguasaan lahan dan sebagian 
besar lahan kopi terutama di wilayah Kabupaten Bondowoso kategori tanah perhutani dan hutan lindung dimana tanaman kopi berada di sela-sela tegakan pohon-pohon besar hutan produktif/ lindung milik pemerintah, sehingga jumlah pohon juga tidak standar. Berdasarkan Tabel 1 dapat dilihat bahwa rata-rata skala usaha petani kopi dalam kategori kecil dan tidak ada perbedaan yang signifikan antara skala usaha petani kopi organik dan non organik. Hal ini terjadi karena petani kopi sangat minim peralatan pengolahan kopi untuk pengolahan sekunder dan tersier. Kalau ada tersedia peralatan dan mesin kebanyakan bukan milik petani kopi pribadi tetapi milik bersama yang disimpan di ketua kelompok atau ketua Gapoktannya masing-masing. Sebagian besar petani beralasan bahwa investasi alat pengolahan dirasa masih mahal dan pemeliharannya juga merasa berat.
Tingkat dan Perbedaan Dukungan Penyuluhan kepada Petani Kopi Organik dan Non Organik

Dukungan penyuluhan pemerintah untuk seluruh petani kopi dalam kategori rendah dengan total rataan skor 34,3 (Tabel 2). Wawancara mendalam dengan petani kopi dan para penyuluh menguatkan bahwa program-program terkait penyuluhan perkebunan kopi masih terbatas pada segi dana, jumlah penyuluh dan kompetensi penyuluh perkopian. Selain itu, lokasi medan perkebunan kopi yang mayoritas berada diperbukitan, pegunungan dan hutan yang sulit dijangkau menjadi kendala dalam koordinasi dan pelaksanaan penyuluhan. Hal ini sesuai dengan hasil penelitian Gunawan dkk. (2019), bahwa dukungan penyuluhan dari pemerintah masih rendah pada petani organik. Dukungan penyuluhan pada petani non organik relatif lebih besar dibandingkan

Tabel 2

Sebaran, Rataan dan Perbedaan Dukungan Penyuluhan Pemerintah pada Petani Kopi di Kabupaten Bondowoso dan Malang Jawa Timur

\begin{tabular}{|c|c|c|c|c|c|}
\hline \multirow{2}{*}{$\begin{array}{c}\text { Aspek Dukungan } \\
\text { Penyuluhan Pemerintah }\end{array}$} & \multirow{2}{*}{ Kategori } & \multicolumn{2}{|c|}{$\begin{array}{l}\text { Petani Kopi Kabupaten } \\
\text { Bondowoso dan Malang }\end{array}$} & \multirow{2}{*}{$\begin{array}{c}\text { Total } \\
(\mathrm{n}=376)\end{array}$} & \multirow{2}{*}{$\begin{array}{l}\text { Uji Beda } \\
\text { (T-test) }\end{array}$} \\
\hline & & $\begin{array}{c}\text { Organik } \\
(n=120)(\%)\end{array}$ & $\begin{array}{l}\text { Non-organik } \\
(\mathrm{n}=256)(\%)\end{array}$ & & \\
\hline \multirow{4}{*}{$\begin{array}{l}\text { Peran sebagai mediator } \\
\text { dan motivator } \\
\text { (X2.1) }\end{array}$} & Rendah & 35,0 & 25,0 & 28,2 & \multirow{4}{*}{$0,00^{* *}$} \\
\hline & Sedang & 28,3 & 50,4 & 43,4 & \\
\hline & Tinggi & 36,7 & 24,6 & 28,5 & \\
\hline & Skor Rataan & 52,4 & 53,1 & 52,9 & \\
\hline \multirow{4}{*}{$\begin{array}{l}\text { Ketepatan Metode } \\
\text { Penyuluhan } \\
\text { (X2.2) }\end{array}$} & Rendah & 39,2 & 55,1 & 50,0 & \multirow{4}{*}{0,56} \\
\hline & Sedang & 51,7 & 32,4 & 38,6 & \\
\hline & Tinggi & 9,2 & 12,5 & 11,4 & \\
\hline & Rataan (skor) & 41,3 & 37,7 & 38,8 & \\
\hline \multirow{4}{*}{$\begin{array}{l}\text { Kesesuaian Materi } \\
\text { Penyuluhan (X2.3) }\end{array}$} & Rendah & 61,7 & 57,0 & 58,5 & \multirow{4}{*}{0,09} \\
\hline & Sedang & 34,2 & 36,7 & 35,9 & \\
\hline & Tinggi & 4,2 & 6,3 & 5,6 & \\
\hline & Skor Rataan & 27,9 & 31,1 & 30,1 & \\
\hline Pemanfaatan Teknologi & Rendah & 90,0 & 86,7 & 87,7 & \multirow{3}{*}{$0,00^{* *}$} \\
\hline \multirow[t]{3}{*}{ Informasi (X2.4) } & Sedang & 8,3 & 12,5 & 11,2 & \\
\hline & Tinggi & 1,7 & 0,8 & 1,1 & \\
\hline & Skor Rataan & 12,4 & 18,7 & 16,7 & \multirow[b]{2}{*}{ (Rendah) } \\
\hline \multicolumn{2}{|l|}{ Total Rataan skor (X2) } & $\begin{array}{l}\text { (Rendah): } \\
\quad 33,5\end{array}$ & $\begin{array}{l}\text { (Sedang): } \\
\quad 35,1\end{array}$ & 34,3 & \\
\hline
\end{tabular}


pada petani kopi organik. Aspek dukungan penyuluhan pemerintah yang memiliki perbedaan sangat signifikan adalah aspek peran sebagai mediator dan motivator, dan pemanfaatan teknologi informasi. Sesuai dengan data di lapang bahwa petani kopi masih rendah dalam penggunaan teknologi informasi untuk pengembangan usahatani kopi. Sumber informasi berbasis teknologi informasi tersebut yang sering dipakai petani kopi adalah urutan pertama Handphone, kedua; WhatsApp, ketiga: Website keempat: Facebook, dan terakhir: Youtube. Oleh sebab itu, agar lebih efektif dalam kegiatan penyuluhan pemanfaatan Handphone dan kelompok WhatsApp sudah bisa dimulai sebagai alternatif media komunikasi pembangunan perkebunan kopi rakyat. Pada aspek ketepatan metode dan kesesuain materi penyuluhan dapat disimpulkan relatif sama.

Dukungan penyuluh swadaya untuk seluruh petani kopi rakyat masuk kategori sedang dengan total rataan skor 43,8 (Tabel 3). Hasil wawancara dengan para petani terungkap bahwa penyuluh swadaya lebih mudah masuk dalam lapisan masyarakat dan lebih memiliki pengalaman yang memadai terkait perkopian karena memang dari praktisi atau petani maju yang berhasil. Selain itu penyuluh swadya memiliki kedekatan sosial yang baik karena hidup dan besar bersama para petani kopi. Hasil uji beda menunjukkan bahwa aspek dukungan penyuluhan swadaya pada petani kopi organik dan non organik berbeda sangat signifikan pada aspek peran sebagai fasilitator dan motivator, sedangkan aspek peran sebagai mediator relatif sama. Kondisi ini terjadi karena mayoritas petani kopi rakyat non organik masih pada tahan membutuhkan fasilitas dan motivasi peningkatan mutu untuk meningkatkan nilai tambah yaitu pengolahan sekunser dan tersier dari petugas penyuluh swadaya. Fokus pendampingan penyuluh swadaya kepada petani prioritas masih pada peningkatan mutu kopi non organik.

Dukungan penyuluh swasta untuk seluruh petani kopi rakyat masuk kategori rendah dengan total rataan skor 25,5 (Tabel 4). Hasil uji beda menunjukkan bahwa aspek dukungan penyuluhan

Tabel 3

Sebaran, Rataan dan Perbedaan Dukungan Penyuluh Swadaya pada Petani Kopi di Kabupaten Bondowoso dan Malang Provinsi Jawa Timur

\begin{tabular}{|c|c|c|c|c|c|}
\hline \multirow[t]{2}{*}{$\begin{array}{l}\text { Aspek Dukungan } \\
\text { Penyuluh Swadaya }\end{array}$} & \multirow[t]{2}{*}{ Kategori } & \multicolumn{2}{|c|}{$\begin{array}{l}\text { Petani Kopi Kabupaten } \\
\text { Bondowoso dan Malang }\end{array}$} & \multirow[t]{2}{*}{$\begin{array}{l}\text { Total } \\
(n=376)\end{array}$} & \multirow[t]{2}{*}{$\begin{array}{l}\text { Uji Beda } \\
\text { (T-test) }\end{array}$} \\
\hline & & $\begin{array}{l}\text { Organik } \\
(n=120)(\%) \\
\end{array}$ & $\begin{array}{l}\begin{array}{l}\text { Non organik } \\
(\mathrm{n}=256)(\%)\end{array} \\
\end{array}$ & & \\
\hline \multirow{4}{*}{$\begin{array}{l}\text { Peran sebagai fasilitator } \\
\text { (X3.1) }\end{array}$} & Rendah & 63,3 & 64,1 & 63,8 & \multirow[t]{4}{*}{$0,00^{* *}$} \\
\hline & Sedang & 20,8 & 10,9 & 14,1 & \\
\hline & Tinggi & 15,8 & 25,0 & 22,1 & \\
\hline & Skor Rataan & 42,4 & 43,1 & 42,9 & \\
\hline \multirow{4}{*}{$\begin{array}{l}\text { Peran sebagai } \\
\text { motivator (X3.2) }\end{array}$} & Rendah & 66,7 & 62,9 & 64,1 & \multirow[t]{4}{*}{$0,00^{* *}$} \\
\hline & Sedang & 24,2 & 14,8 & 17,8 & \\
\hline & Tinggi & 9,2 & 22,3 & 18,1 & \\
\hline & Skor Rataan & 37,6 & 44,3 & 42,2 & \\
\hline \multirow{4}{*}{$\begin{array}{l}\text { Peran sebagai mediator } \\
\text { (X3.3) }\end{array}$} & Rendah & 52,5 & 65,6 & 61,4 & \multirow[t]{4}{*}{0,25} \\
\hline & Sedang & 20,0 & 7,8 & 11,7 & \\
\hline & Tinggi & 27,5 & 26,6 & 26,9 & \\
\hline & Skor Rataan & 51,3 & 44,4 & 46,6 & \\
\hline Total Rataan skor (X3) & & Sedang 43,8 & Sedang 43,9 & 43,8 & Sedang \\
\hline
\end{tabular}


Tabel 4

Sebaran, Rataan dan Perbedaan Dukungan Penyuluh Swasta pada Petani Kopi di Kabupaten Bondowoso dan Malang Provinsi Jawa Timur

\begin{tabular}{|c|c|c|c|c|c|}
\hline \multirow{2}{*}{$\begin{array}{l}\text { Aspek Dukungan } \\
\text { Penyuluh Swasta }\end{array}$} & \multirow{2}{*}{ Kategori } & \multicolumn{2}{|c|}{$\begin{array}{l}\text { Petani Kopi Kabupaten } \\
\text { Bondowoso dan Malang }\end{array}$} & \multirow{2}{*}{$\begin{array}{c}\text { Total } \\
(n=376)\end{array}$} & \multirow{2}{*}{$\begin{array}{c}\text { Uji } \\
\text { Beda } \\
\text { (T-test) }\end{array}$} \\
\hline & & $\begin{array}{c}\text { Organik } \\
(n=120)(\%)\end{array}$ & $\begin{array}{l}\text { Non organik } \\
(n=256)(\%)\end{array}$ & & \\
\hline \multirow{4}{*}{$\begin{array}{l}\text { Peran sebagai } \\
\text { fasilitator }(X 4.1)\end{array}$} & Rendah & 81,7 & 96,1 & 91,5 & $0,00^{* *}$ \\
\hline & Sedang & 15,8 & 3,9 & 7,7 & \\
\hline & Tinggi & 2,5 & 0,0 & 0,8 & \\
\hline & Skor Rataan & 31,5 & 21,1 & 24,4 & \\
\hline \multirow{4}{*}{$\begin{array}{l}\text { Peran sebagai motivator } \\
\text { (X4.2) }\end{array}$} & Rendah & 81,7 & 96,5 & 91,8 & $0,00^{* *}$ \\
\hline & Sedang & 10,8 & 2,7 & 5,3 & \\
\hline & Tinggi & 7,5 & 0,8 & 2,9 & \\
\hline & Skor Rataan & 31,7 & 22,1 & 25,1 & \\
\hline \multirow{4}{*}{$\begin{array}{l}\text { Peran sebagai mediator } \\
\text { (X4.3) }\end{array}$} & Rendah & 80,0 & 97,3 & 91,8 & $0,00^{* *}$ \\
\hline & Sedang & 10,8 & 2,3 & 5,1 & \\
\hline & Tinggi & 9,2 & 0,4 & 3,2 & \\
\hline & Skor Rataan & 36,1 & 22,0 & 26,5 & \\
\hline Total Rataan skor (X4) & & Rendah & Rendah 21,7 & 25,5 & Rendah \\
\hline
\end{tabular}

Keterangan : Skor: Rendah (0-34), Sedang (35-69), Tinggi (70-100)

${ }^{* *}$ Berbeda sangat signifikan pada taraf $(0,01), \quad$ *berbeda signifikan pada taraf $(0,05)$

Sumber: Pengolahan Data Primer 2019

swasta pada petani kopi organik dan non organik berbeda sangat signifikan pada semua aspek baik peran sebagai fasilitator, motivator dan mediator. Hal ini dapat dijelaskan bahwa penyuuh swasta sangat tertarik pada petani kopi organik sehingga lebih intensif untuk dikunjungi dan diberi penyuluhan. Selain itu kelompok tani kopi rakyat yang dijadikan percontohan untuk pengembangan organik sering mendapatkan bantuan biaya/modal usaha, fasilitas baru dari berbagai pihak sehingga pihak perusahaan swasta berusaha menjalin komunikasi untuk membuka peluang kerja sama bisnis maupun bina lingkungan sosial.

Faktor-faktor yang Berpengaruh terhadap Keputusan Petani Kopi Rakyat dalam Pemilihan Sistem Kopi Organik dan Non Organik.

Keputusan petani kopi untuk mengadopsi sistem perkebunan kopi organik dipengaruhi oleh persepsi petani terkait keunggulan dalam melakukan perkebunan organik. Persepsi petani kopi dalam mengambil keputusan melakukan per- kebunan kopi organik dipengaruhi oleh faktor pertama; karakteristik individu petani yaitu; umur, pendidikan formal, pendidikan non formal, pengalaman berusahatani, motivasi pengembangan usaha, penguasaan lahan, kekosmopolitan, skala usaha tani. Kedua: dukungan penyuluh pemerintah, swadaya dan swasta. Uji yang dilakukan menggunakan analisis regresi binary logit. Variabel bebas (independent) yang berpengaruh signifikan terhadap pengambilan keputusan petani melakukan perkebunan kopi organik adalah pengalaman berusahatani, motivasi pengembangan usaha, dan kekos-mopotitan petani kopi. Untuk dukungan penyuluhan yang berpengaruh signifikan terhadap pengembangan kopi organik yaitu peran penyuluh swadaya dan penyuluh swasta. Penjelasan analisis logit pada masingmasing variabel bebas disajikan pada Tabel 5. Umur tidak berpengaruh signifikan terhadap keputusan petani melakukan perkebunan kopi organik. Kondisi ini sesuai dengan data lapang bahwa rata-rata umur petani organik dan non organik memang tidak jauh berbeda. Koefisien hasil output 
yang diperoleh bernilai positif yang menunjukkan semakin tinggi umur petani keputusan petani kopi untuk melakukan perkebunan kopi organik semakin besar. Berbeda dengan laporan Amanah \& Tjitropranoto (2018), bahwa umur petani berpengaruh signifikan terhadap perilaku beragribisnis.

Variabel pendidikan non formal berpengaruh signifikan terhadap keputusan petani melakukan perkebunan kopi organik. Koefisien hasil output yang diperoleh bernilai negatif menunjukkan semakin rendah pendidikan non formal petani keputusan petani kopi untuk melakukan perkebunan kopi non organik semakin besar. Hal ini berbeda dengan hasil penelitian Anisah \& Hayati (2017), bahwa pada karakteristik petani pendidikan non formal tidak berpengaruh signifikan terhadap penerapan GAP kopi.

Variabel pengalaman berpengaruh tidak signifikan terhadap keputusan petani melakukan perkebunan kopi organik. Koefisien hasil output yang diperoleh bernilai positif artinya semakin tinggi pengalaman yang dimiliki petani maka keputusan petani untuk ke kopi organik lebih besar. Menurut laporan Anisah \&
Hayati (2017), bahwa pengalaman petani berpengaruh positif terhadap pengambilan keputusan dalam ikut serta anggota kelompok. Berbeda dengan penelitian Rizki dkk. (2017), bahwa pengalaman berkorelasi signifikan dengan motivasi berusahatani.

Variabel motivasi berpengaruh sangat signifikan terhadap keputusan petani melakukan perkebunan kopi organik. Koefisien hasil output yang diperoleh bernilai positif artinya semakin tinggi motivasi petani semakin tinggi pula peluang untuk melakukan perkebunan kopi organik. Temuan ini sesuai dengan hasil penelitian Rizki dkk. (2017), bahwa motivasi petani kopi berkorelasi signifikan dengan persepsi perkebunan kopi organik. Managanta dkk. (2019), juga menemukan bahwa motivasi petani berpengaruh signifikan dengan tingkat kompetensi petani.

Pendidikan formal berpengaruh signifikan terhadap keputusan petani melakukan perkebunan kopi organik. Mayoritas petani kopi lulus pendidikan formal hanya tingkat SD dan SMP. Koefisien hasil output yang diperoleh bernilai negatif, maka menunjukkan semakin rendah pendidikan formal keputusan petani kopi

Tabel 5

Faktor-faktor yang Berpengaruh terhadap Pengambilan Keputusan dalam Memilih Sistem Kopi Organik dan Non Organik di Provinsi Jawa Timur

\begin{tabular}{llll}
\hline Faktor-faktor & Koefisien B & Wald & Signifikansi \\
\hline Umur petani (X1.1) & 0,000 & 0,059 & 0,808 \\
Pendidikan formal (X1.2) & $-0,002$ & 9,895 & $0,002^{*}$ \\
Pendidikan non formal (X1.3) & -4.584 & 6,440 & $0,011^{*}$ \\
Pengalaman berusahatani (X1.4) & 0,000 & 2,271 & 0,132 \\
Motivasi berusaha (X1.5) & 0,000 & 13,735 & $0,000^{* *}$ \\
Penguasaan lahan (X1.6) & $-0,002$ & 1,535 & 0,215 \\
Kekosmopolitan (X1.7) & 0,001 & 6.095 & $0,014^{*}$ \\
Skala usaha (X1.8) & 0,000 & 0,705 & 0,401 \\
Penyuluhan pemerintah (X2) & $-0,006$ & 0,307 & 0,579 \\
Penyuluh swadaya (X3) & $-0,017$ & 6,202 & $0,013^{*}$ \\
Penyuluh swasta (X4) & 0,080 & 36,807 & $0,000^{* *}$ \\
Contanta & 4,335 & 4,398 & $0,036^{*}$ \\
Chi-Square & 108,7 & & $0,000^{* *}$ \\
Nagelkerke R-square & 0,532 & & \\
Classification plot & $81,4 \%$ & & \\
\hline
\end{tabular}

Keterangan :** Sangat signifikan pada taraf $(0,01)$, *signifikan pada taraf $(0,05)$

Sumber: Data Primer Diolah, 2019 
untuk melakukan perkebunan kopi non organik semakin besar. Sesuai pendapat Rizki dkk. (2017), bahwa pendidikan formal petani kopi berkorelasi signifikan dengan persepsi perkebunan kopi organik. Hasil penelitian Managanta dkk. (2019), juga mengemukakan pendidikan formal berpengaruh signifikan dengan tingkat kompetensi petani perkebunan rakyat.

Penguasaan lahan tidak berpengaruh signifikan terhadap keputusan petani melakukan perkebunan kopi organik. Koefisien hasil output yang diperoleh bernilai negatif menunjukkan semakin rendah penguasaan lahan keputusan petani kopi untuk melakukan perkebunan kopi organik semakin besar. Kondisi ini mengindikasikan bahwa inovasi pertanian kopi organik masih tahap uji coba oleh sebagian besar petani sehingga skala lahan yang dikonversikan masih relatif sempit atau tidak luas. Petani kopi masih pada tahap konfirmasi keuntungan relatifnya terhadap inovasi sistem organik. $\mathrm{Hal}$ ini sesuai dengan hasil penelitian Ryan dkk. (2018), bahwa luas lahan petani tidak bepengaruh terhadap kecepatan adopsi.

Variabel kekosmopolitan berpengaruh sangat signifikan terhadap keputusan petani melakukan perkebunan kopi organik. Koefisien hasil output yang diperoleh bernilai positif artinya semakin tinggi kekosmopolitan petani maka keputusan petani untuk beralih ke kopi organik semakin tinggi. Kekosmopolitan petani kopi supaya meningkat maka pembangunan akses sarana jalan dan jaringan komunikasi sebaiknya terus ditingkatkan. Hal ini sesuai dengan hasil penelitian Sari dkk. (2016) dan Managanta dkk. (2019), bahwa kekosmopolitan mempengaruhi kinerja dan kompetensi petani. Skala usaha petani kopi tidak berpengaruh signifikan terhadap keputusan petani melakukan perkebunan kopi organik. Hal ini dapat dijelaskan berdasarkan data empiris bahwa sebagan besar petani kopi rakyat masih pada skala pengolahan primer dan sebagian kecil skala pengolahan sekunder dan tersier. Namun, koefisien hasil output yang diperoleh bernilai positif yang menunjukkan semakin tinggi skala usaha petani keputusan petani kopi untuk melakukan perkebunan kopi organik semakin besar. Hal ini relevan dengan keberanian petani kopi dalam mengambil risiko usaha, semakin tinggi skala pengolahan maka semakin baik tingkat diversifikasi produk kopinya sehingga lebih berani mengambil risiko mencoba inovasi teknologi baru.

Penyuluhan pemerintah tidak berpengaruh signifikan terhadap keputusan petani melakukan perkebunan kopi organik. Hal ini terjadi karena banyak petani kopi yang merasa penyuluhan pemerintah masih kurang optimal dan cenderung fokus pada penyuluhan komoditas tanaman pangan. Selain itu komoditas kopi merupakan produk khas sehingga dibutuhkan kompetensi penyuluh yang monovalent, padahal tidak semua penyuluh ahli di bidang perkopian. Koefisien hasil output yang diperoleh bernilai negatif yang menunjukkan semakin rendah penyuluhan pemerintah keputusan petani kopi untuk melakukan perkebunan kopi non organik semakin besar. Lebih lanjut, petani kopi kayat butuh peningkatan penyuluhan pemerintah dengan aktivitas penyuluhan yang lebih intensif dan sesuai dengan kebutuhan petani kopi. Hal ini sesuai dengan temuan Wardani \& Anwarudin (2018), bahwa peran penyuluhan pertanian tidak berpengaruh signifikan terhadap regenerasi petani.

Penyuluh swadaya berpengaruh signifikan terhadap keputusan petani melakukan perkebunan kopi organik. Koefisien hasil output yang diperoleh bernilai negatif artinya semakin rendah penyuluhan swadaya maka keputusan petani untuk tetap pada perkebunan kopi non organik lebih besar. Hal ini sesuai dengan data lapang bahwa penyuluh swadaya yang merupakan petani maju masih banyak yang ragu dengan sistem pertanian kopi organik. Banyak petani kopi organik mengalami kesulitan dalam pemasaran dan menjual dengan harga yang layak/sesuai jerih payahnya sebagai petani organik. Pengembangan kopi organik memerlukan peran penyuluh 
swadaya yang merupakan orang dalam dalam sistem sosialnya, mengingat keputusan inovasi petani banyak yang masih tergantung pada opinion leadernya. Hal ini sesuai dengan hasil penelitian Syahyuti (2016), yang menyatakan pe-nyuluh swadaya memiliki posisi sosial strategis dan khas. Haryanto (2017), juga melaporkan bahwa penyuluh swadaya berperan efektif dalam pemberdayan petani. Managanta dkk. (2019), juga me-ngemukakan bahwa peran penyuluh berpengaruh signifikan dengan tingkat kompetensi petani.

Penyuluh swasta berpengaruh sangat signifikan terhadap keputusan petani melakukan perkebunan kopi organik. Koefisien hasil output yang diperoleh bernilai positif artinya semakin tinggi penyuluhan swasta maka keputusan petani untuk beralih ke kopi organik semakin tinggi. Untuk kedepannya kepastian dan regulasi terkait peran penyuluh swasta bagi petani kopi dapat membantu pengembangan perkebunan organik. Hal ini sesuai dengan pendapat Syahyuti (2016), kapasitas penyuluh swasta bersifat khas dan tidak dapat menggantikan keseluruhan peran penyuluh pemerintah. Suryanti dkk. (2019), juga mengemukakan bahwa penyuluh swasta memiliki pengaruh kuat terhadap peningkatan kapasitas petani. Managanta dkk. (2019), juga mengemukakan bahwa peran penyuluh berpengaruh signifikan dengan tingkat kompetensi petani.

\section{SIMPULAN}

Terdapat perbedaaan yang signifikan pada dukungan penyuluhan dan karakteristik petani kopi organik dan non organik yaitu; peran penyuluhan sebagai fasilitator, motivator dan mediator, pemanfaatan teknologi informasi, umur petani, pengalaman, motivasi dan tingkat kekosmopolitan, sedangkan pendidikan formal dan non formal, penguasaan lahan dan skala usaha relatif sama. Tingkat pendidikan non formal petani, skala usaha, penguasaan lahan, kekosmopolitan, dukungan penyuluhan pemerintah, swasta pada kategori rendah, sedangkan faktor umur petani, pendidikan formal, motivasi, pengalaman, dukungan penyuluh swadaya pada kategori sedang. Dengan demikian dapat disimpulkan penerapan sistem kopi organik di wilayah Jawa Timur masih pada tahap konfirmasi. Faktor-faktor yang berpengaruh kuat terhadap pengambilan keputusan petani kopi rakyat dalam penerapan sistem kopi organik yaitu; tingkat pendidikan formal, pendidikan non formal, motivasi berusaha, kekosmopolitan petani, penyuluh swadaya dan swasta. Peran utama penyuluhan swadaya dan swasta dalam bentuk fasilitasi, mediasi dan motivasi langsung kepada petani kopi rakyat. Pemerintah untuk segera meningkatkan kemampuan dan kompetensi penyuluh swadaya dan swasta terkait pengembangan pertanian kopi organik melalui kegiatan pendidikan non formal dengan sinergi dukungan program kemitraan pemerintah, swadaya dan swasta agar motivasi dan kapasitas petani kopi rakyat terus menguat. Selain itu, petani kopi rakyat yang sudah mulai beralih ke kopi organik butuh jaminan akses pemasaran, kontinyuitas permintaan, dan harga yang layak serta sinergi pendampingan dari pihak pemerintah dan swasta (agen pedagang, eksporter, perusahaan).

\section{Ucapan Terima Kasih}

Ucapan terima kasih yang sebesarbesarnya kepada para penyuluh, enumerator, petani kopi rakyat dan Kementrian Pendidikan dan Kebudayan yang telah memberikan beasiswa program Doktoral BPPDN dengan No.SK 2903/ D3/PG/2017 sehingga penelitian ini dapat terlaksana.

\section{DAFTAR PUSTAKA}

Aklimawati, L., Sumarno, D., \& Mawardi, S. (2015). Effect of Service Quality on Coffee Based Economic Cluster Development on Farmers and other Stakeholders Satisfaction in Bondowoso District. Pelita Perkebunan (a Coffee and Cocoa Research Journal), 31(1), 59-72. 
Amanah, S., \& Tjitropranoto, P. (2018). Tingkat Adopsi Good Agricultural Practices Budidaya Kopi Arabika Gayo oleh Petani di Kabupaten Aceh Tengah. Jurnal Penyuluhan, 14(2). https://doi.org/10.25015/ penyuluhan.v14i2.19757

Anisah, A., \& Hayati, M. (2017). Pengambilan Keputusan Petani untuk Tetap Berusahatani Cabe Jamu di Kecamatan Bluto, Sumenep. AGRARIS: Journal of Agribusiness and Rural Development Research, 3(2). $\quad$ https://doi.org/10.18196/ agr.3251

Arikunto S. (2010). Prosedur Penelitian; Suatu Pendekatan Praktek. Jakarta: PT Rineka Cipta.

D. I. A. Pratama, B. M. Setiawan, E. (2018). Comparative Analysis Of Semi Organic And Non Organic Paddy Comparative In Sub District Undaan Kudus Regency. Jurnal Agrisocionomics. 2(1), 14-22.

Direktur Jenderal Perkebunan. (2017). Statistik Perkebunan Indonesia; Komoditas Kopi. Jakarta.

Fatmalasari, M., Prasmatiwi, F. E., \& Rosanti, N. (2016). The Analyze of Indonesian Organic Farm Certification (INOFICE) Benefits Toward The Development of Organic Coffee Farm Sustainability In Air Hitam Sub District Lampung Barat District. Jiia, 4(1), 94-103.

Gani, A. A. (2008). Analisis Komparatif Pendapatan Petani Kopi Organik dan Petani Kopi Anorganik di Dataran Tinggi Gayo Nanggroe Aceh Darussalam. Jurnal IImiah ESAI, 2(2).
Gunawan, Aida Vitayala S Hubeis, Anna Fatchiya, D. S. (2019). Dukungan Penyuluhan dan Lingkungan Ekternal terhadap Adopsi Inovasi dan Keberlanjutan Usaha Pertanian Padi Organik. Agriekonomika, 8(1), 70-80. https://doi.org/DOI: http://doi. org/10.21107/

Hafif, B., Prastowo, B., \& Prawiradiputra, B. R. (2014). Pengembangan Perkebunan Kopi Berbasis Inovasi di Lahan Kering Masam. Pengembangan Inovasi Pertanian, 7(4), 199-206.

Haryanto, et al. (2017). Penyuluh kontrak Tenaga Harian Lepas Tenaga. Jurnal Pengkajian Dan Pengembangan Teknologi Pertanian, 20(2), 141-154.

Hawkins dan Van den Ban. (1999). Penyuluhan Pertanian. Yogyakarta: Kanisius.

Managanta, A. A., Sadono, D., \& Tjitropranoto, P. (2019). Faktorfaktor yang Berpengaruh terhadap Kompetensi Petani Kakao di Provinsi Sulawesi Tengah. Jurnal Penyuluhan, 15(1).

Mayrowani, H. (2013). Kebijakan Penyediaan Teknologi Pascapanen Kopi dan Masalah Pengembangannya. Forum Penelitian Agro Ekonomi, 31(1), 31. https://doi.org/10.21082/fae. v31n1.2013.31-49

Rizki, A., Widyawati, \& Agussabti. (2017). Persepsi Petani Kopi Arabika terhadap Program Sertifikasi Organik di Kecamatan Atu Lintang Kabupaten Aceh Tengah. Jurnal IImiah Mahasiswa Pertanian Unsyiah, 2(1), 244-249. https://doi. org/10.1590/0074-02760190033.14 
Rubiyo, Guntoro, S., Suprapto. (2003). Usahatani Kopi Robusta dengan Pemanfaatan Kotoran Kambing sebagai Pupuk Organik di Bali. Jurnal Pengkajian dan Pengembangan Teknologi Pertanian, 6(1), 73-80.

Ruhimat, I. S. (2015). Tingkat Motivasi Petani Dalam Penerapan Sistem Agroforestry. Jurnal Penelitian Sosial Dan Ekonomi Kehutanan, 12(2), 131-147.

Ryan, E., Prihtanti, T. M., \& Nadapdap, H. J. (2018). Faktor-Faktor yang Mempengaruhi Adopsi Petani terhadap Penerapan Sistem Pertanian Jajar Legowo di Desa Barukan Kecamatan Tengaran Kabupaten Semarang. Prosiding Seminar Nasional Fakultas Pertanian UNS, 2(1), 53-64. http://jurnal.fp.uns. ac.id/index.php/semnas/article/ view/1179/769

Saragih, J. R. (2018). Aspek Ekologis dan Determinan Produksi Kopi Arabika Spesialti di Wilayah Dataran Tinggi Sumatera Utara. Jurnal Wilayah Dan Lingkungan, 6(2), 74. https://doi. org/10.14710/jwl.6.2.74-87

Sari, N. M. W., Suwarsinah, H. K., \& Baga, L. M. (2016). Pengaruh Karakteristik Kewirausahaan terhadap Kinerja Usaha Mikro, Kecil dan Menengah(UMKM) Gula Aren di Kabupaten Lombok Barat, Nusa Tenggara Barat, Indonesia. Jurnal Penyuluhan, 12(1), 51-60. https:// doi.org/10.25015/penyuluhan. v12i1.11320
Sumarti, T., Rokhani, R., \& Falatehan, S.

F. (2017). Strategi Pemberdayaan Petani Muda Kopi Wirausaha di Kabupaten Simalungun. Jurnal Penyuluhan, 13(1), 31. https:// doi.org/10.25015/penyuluhan. v13i1.15165

Suryanti, R., Sumardjo, Syahyuti, \& Tjitropranoto, P. (2019). The role of Private Extension Agents in Broiler Farmer Business Capacity Building Using a Sem Lisrel. International Journal of Innovative Technology and Exploring Engineering, 9(1), 996-1001. https://doi.org/10.35940/ ijitee.A4597.119119

Syahyuti, N. (2016). Peran Strategis Penyuluh Swadaya dalam Paradigma Baru Penyuluhan Pertanian Indonesia. Forum Penelitian Agro Ekonomi, 32(1), 43. https://doi. org/10.21082/fae.v32n1.2014.43-58

Wardani, \& Anwarudin, O. (2018). Peran Penyuluh terhadap Penguatan Kelompok Tani dan Regenerasi Petani di Kabupaten Bogor Jawa Barat. Jurnal TABARO, 2(1), 191200. 